\title{
20(S)-Ginsenoside Rg3 Promotes Senescence And Apoptosis In Gallbladder Cancer Cells Via The P53 Pathway [Corrigendum]
}

Zhang F, Li M, Wu X, et al. Drug Des Devel Ther. 2015;9:3969-3987.

On page 3976, Figure 3B should be presented as follows:

Following a review of the data post-publication, the authors found two identical cell cycle images in two different groups were placed for $200 \mu \mathrm{M}$ and $400 \mu \mathrm{M}$. We have replaced the image for $400 \mu \mathrm{M}$ in this corrigendum.

The authors confirmed that this error does not affect any statistical results or any relevant conclusions about Figure 3B. The authors apologize for this oversight.
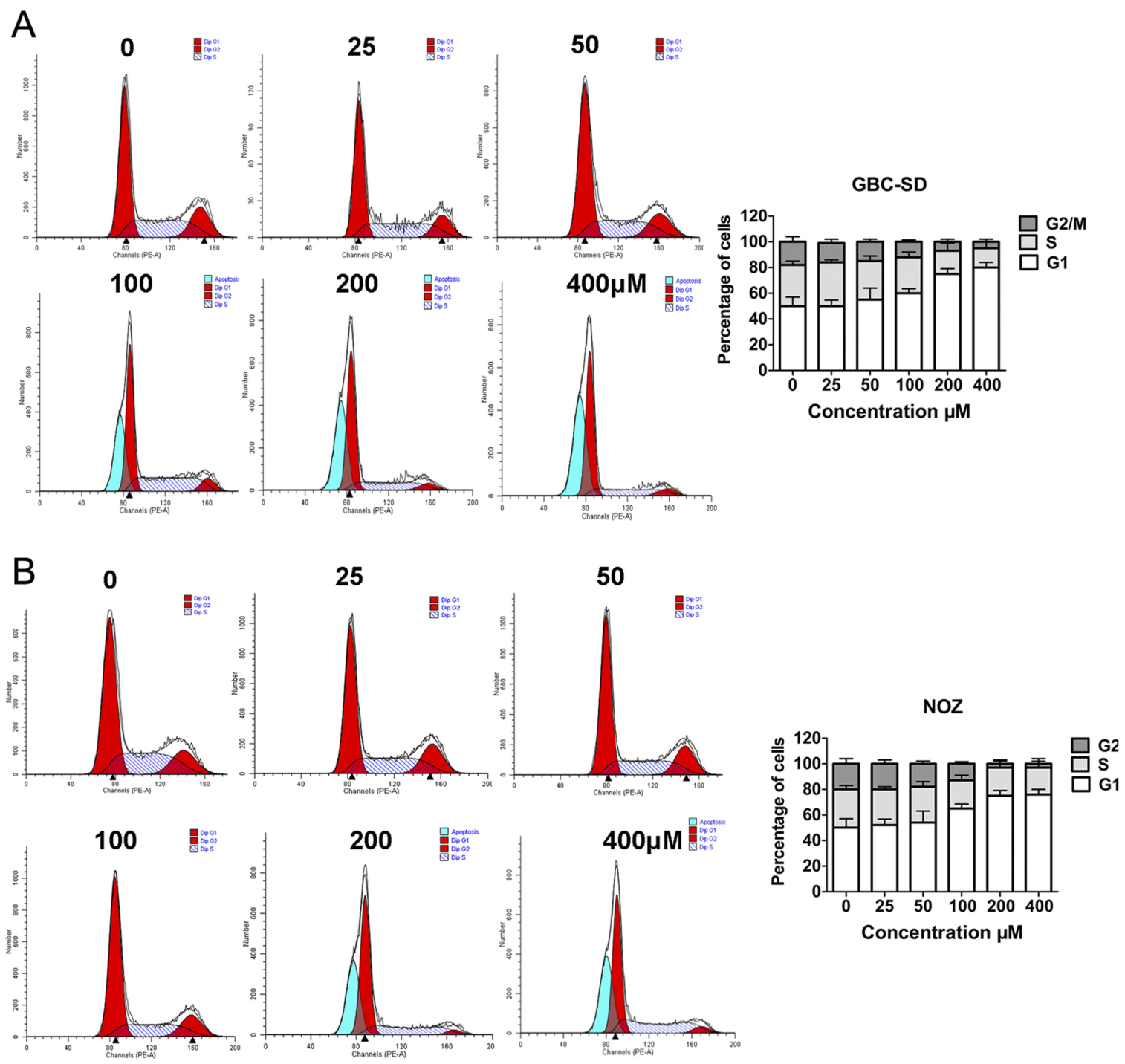

Figure $320(S)-R g 3$ blocks the cell cycle progression of gallbladder cancer cells.

Notes: (A, B) The cell cycle phases of the treated cells were evaluated by flow cytometry. (C) Western blot analysis of cell cycle-related proteins in both cell lines. $\beta$-actin was used as a loading control. Data represent the mean \pm SD of three independent experiments.

Abbreviation: SD, standard deviation. 
C

$\mathrm{NOZ}$

p21

\section{Cyclin B1}

\section{Cyclin A}

$\beta$-actin
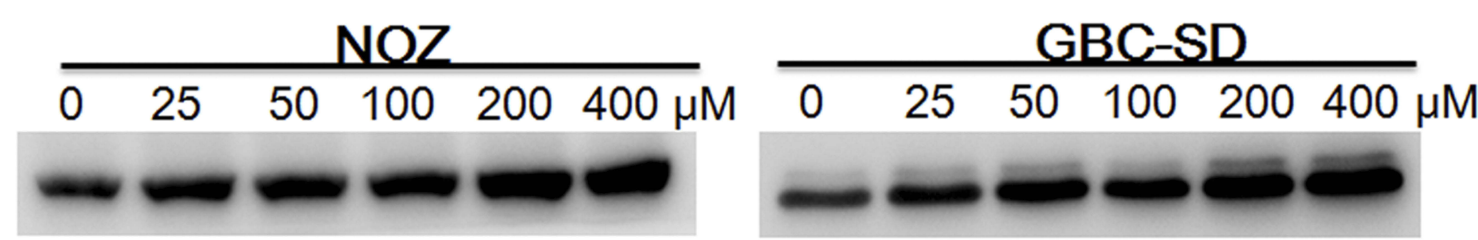

GBC-SD

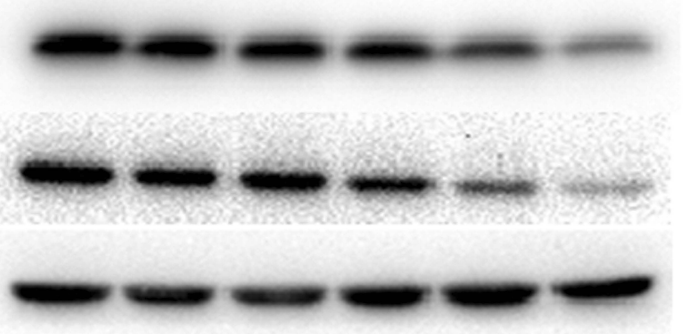

Figure 3 Continued.

\section{Publish your work in this journal}

Drug Design, Development and Therapy is an international, peerreviewed open-access journal that spans the spectrum of drug design and development through to clinical applications. Clinical outcomes, patient safety, and programs for the development and effective, safe, and sustained use of medicines are a feature of the journal, which has also been accepted for indexing on PubMed Central. The manuscript management system is completely online and includes a very quick and fair peer-review system, which is all easy to use. Visit http://www. dovepress.com/testimonials.php to read real quotes from published authors. 